\title{
SOL DE FEIRA, DE LUIZ BACELLAR: CULTURA E IMAGINÁRIO AMAZÔNICO NO POMAR DA FICÇÃO
}

\author{
SOL DE FEIRA BY LUIZ BACELLAR: AMAZONIC CULTURE AND \\ IMAGINARY IN ORCHARD OF THE FICTION
}

\author{
Lidiane Barreto Costa Neves ${ }^{1}$ \\ ORCID: 0000-0002-3987-0367
}

\begin{abstract}
Resumo: Estudo situado no âmbito da teoria literária, vinculado à literatura de expressão amazônica que objetiva realizar uma análise crítica dos poemas rondel da castanha, rondel do tucumã e rondel do abiu, presentes no livro Sol de Feira, de Luiz Bacellar, no sentido de investigar como o poeta recria importantes elementos da cultura e do imaginário amazônico. Sol de Feira é um inventivo livro de poesia em que cada poema é dedicado a uma fruta da Amazônia. E cada fruta, por meio do recurso da alegoria, transforma-se em um exemplar expressivo de elementos da cultura e do imaginário de indígenas caboclos e demais amazônidas. A pesquisa apresenta reflexões teóricas sobre a arte literária, explorando a teoria dos bosques da ficção, de Umberto Eco, e o conceito de alegoria. Apresenta também um painel sobre a cultura amazônica. Esse quadro teórico instrumentaliza a imersão nos poemas do Bacellar, com vistas a investigar como o universo amazônico e suas contingências são recriados na obra, por meio da oficina poética.
\end{abstract}

Palavras-chave: Amazônia; Ficção; Alegoria; Sol de Feira.

\begin{abstract}
Study situated in the field of the literary theory, linked to literature of Amazonian expression that aims at carrying out a critical analysis of the poem's rondel of the castanha, rondel of the tucuma and rondel of the abiu appears at the book Sol de Feira, by Luiz Bacellar, in the sense of investigating how the poet recreates important elements of the Amazonian culture and imaginary. Sol de Feira is an inventive book of poetry where each poem is dedicated to a fruit of the Amazon. And each fruit, through the resource of the allegory, turns into a significant template of the elements of the culture and the imaginary of indigenous, caboclos and other Amazonians. The article shows theoretical reflections about the literary art, exploring the theory of the fictional woods, by Umberto Eco, and the concept of allegory. It also presents a theoretical framework about Amazonian culture. This theoretical framework instrumentalize an immersion in Bacellar poems, with view to investigate how the Amazonian universe and its contingencies are recreated in the book, by means of the poetic workshops.
\end{abstract}

\footnotetext{
1. Mestranda em Letras - Teoria e Análise Linguística pela Universidade Federal do Amazonas. Graduada em Letras - Língua e Literatura pela mesma universidade. Membro do Grupo de Estudos de Língua Latina de Manaus (GELLAMA).
} 
Keywords: Amazon; Fiction; Allegory; Sol de Feira.

\section{Introdução}

Apesar de ainda ser pouco explorada, a literatura no Amazonas apresenta um vasto leque de variações, especialmente no que diz respeito à poesia. Os poetas amazonenses e suas obras, aos poucos, vão se tornando conhecidos por meio de estudos acadêmicos e científicos, principalmente através do fomento à pesquisa pela Universidade.

Historicamente, o surgimento do Clube da Madrugada (doravante CM), na década de 1950, deu um considerável impulso para a instalação do Modernismo no Amazonas. O CM congregou uma geração de jovens que se uniram com o intuito básico de atualizar as artes no Estado, rompendo com o atraso e o passadismo, e pondo a capital do Amazonas $^{2}$ em sintonia com o que se praticava nos grandes centros do país em termos artísticos e, principalmente, literários. Inicialmente, eram apenas reuniões de discussões políticas, artísticas, filosóficas etc., mas, com o passar do tempo, a agremiação tornou-se um canal de divulgação de obras que foram e continuam sendo marcos da nossa literatura. Dentre os integrantes do CM, destaca-se o nome de Luiz Bacellar, que em sua poesia abre um espaço especial para a cultura local, mostrando as várias facetas culturais do Amazonas: o imaginário do nativo em suas múltiplas formas de realização. Uma das obras produzidas por Bacellar é o livro Sol de Feira (1973), no qual o poeta recria, de forma original, a imagem de dois tipos humanos da região: o caboclo - habitante rural da Amazônia ${ }^{3}$ - e o indígena, sendo ele mesmo, o poeta, nativo da Amazônia. O fato de ser nativo, ter uma visão endógena da cultura regional, possibilita-lhe recriar essas personagens reais do Amazonas, retratandoas como parte de um todo, que abrange tanto a fauna quanto a flora, além da humanidade.

\section{Cultura e imaginário do homem amazônico}

Cultura é um termo abrangente, do qual se pode entender, genericamente, como a expressão de determinado povo, isto é, sua música, suas danças... No entanto, cultura extrapola essas “concepções” genéricas. Franz Boas, importante antropólogo e fundador da "Antropologia Geral", considera que s homens possuem um olhar diferente sobre o seu meio,

\footnotetext{
${ }^{2}$ Refere-se a Manaus.

${ }^{3}$ LIMA, 1999, p. 6.
} 
e esse olhar sofre influência de sua própria cultura; Boas entende como cultura o próprio comportamento humano frente a outros seres humanos e à natureza, por isso ele afirma que estamos acorrentados aos "grilhões da tradição" (BOAS, 2004, p.18, porque sua concepção de cultura é justamente o olhar que temos dos outros e do meio, tomando como perspectiva ou parâmetro nossa própria cultura.

Além da concepção boaseana sobre cultura, o antropólogo brasileiro Laraia (1986, p.68) afirma que "O modo de ver o mundo, as apreciações de ordem moral e valorativa, os diferentes comportamentos sociais e mesmo as posturas corporais são assim produtos de uma herança cultural, ou seja, o resultado da operação de uma determinada cultura", e por isso possuímos percepções diferentes sobre o nosso meio e sobre os outros, como o caboclo e o indígena, que veem o mundo de uma forma diferente das pessoas que vivem na capital amazonense, por exemplo. E isso ocorre pelo movimento cultural que acontece, não somente por que existe, mas pela possibilidade do que se pode vir a ser (SANTOS, 1994, p.18-19), e assim é possível que os estudos culturais sejam um norte para que possamos compreender o comportamento humano e, sobretudo, a visão que cada povo tem sobre o mundo, e como seu imaginário atua sobre ele.

Desta forma, é possível perceber a necessidade dos estudos culturais para que se pense no nativo da Amazônia, representado na obra de Bacellar, e além dos estudos culturais, a importância da imagem e do imaginário para sua construção cultural. Pageaux (2004, p.136) nos diz que a imagem é "a representação de uma realidade cultural através da qual o indivíduo ou o grupo que a elaborou (ou que a partilha, ou que a propaga) revelam e traduzem o espaço cultural e ideológico no qual se situam", a qual também é entendida como expressão literária. Ou seja, a imagem está ligada à literatura, logo, à poesia, gênero que a constitui, e ambas são formas de expressão humana, ou, ainda, uma ferramenta para compreensão da realidade cultural e ideológica de determinado grupo. É por meio de ambas que será possível fazer estudos sobre as várias culturas, podendo ser feitas análises sobre a identidade, o imaginário e a cultura de um povo por meio de obras como Sol de Feira, objeto de estudo deste artigo.

É através do reflexo da imagem que será possível perceber o imaginário:

A imagem deve ser estudada como um objeto, uma prática antropológica e tem o seu lugar e a sua função no universo simbólico nomeado aqui de «imaginário», inseparável de toda a organização social e cultural, uma vez 
que é através dele que uma sociedade se vê a si mesma, se escreve, se pensa e se sonha (PAGEAUX, 2004, p.139).

Ao afirmar que através do imaginário a sociedade "se vê a si mesma, se escreve, se pensa e se sonha", Pageaux trata, precisamente, a relação do imaginário com a sociedade, como ele funcionará para a construção dessa sociedade e da sua cultura, por meio dos mitos, que são agentes de respostas ao questionamento humano e ao desconhecido, possibilitando o despertar da mente humana para a imaginação, fazendo dela sua aliada para soluções e abertura para que seja possível ver a identidade dessa sociedade, uma vez que o imaginário atua na caracterização dessa identidade enquanto marca coletiva de determinado grupo, de quem são. Segundo Castells (1999, p.22), identidade pode ser entendida como "um processo de construção de significado com base em um atributo cultural" ou de um "conjunto de atributos culturais inter-relacionados", e as identidades culturais são construídas por meio de "matéria-prima" advinda da história, da geografia, da biologia ${ }^{4} .$. Todos esses campos participam da construção e da identidade em si, de indivíduos e de um povo.

O imaginário, ainda sob a perspectiva de Pageaux, está integrado na bipolaridade da identidade versus a alteridade, em que esta é vista como um termo oposto e complementar da/à identidade ${ }^{5}$. De acordo com Ceia (2009, p.n.), alteridade é o "facto ou estado de ser Outro, e essa concepção de alteridade pode ser compreendida com base nos estudos fenomenológicos da relação do "Eu" com o "Outro". Sobre a relação do "Eu" e do "Outro", Sartre (2011, p.451-453) entende que, para que seja possível nos perceber, é preciso que, sobretudo, percebamos o outro, e dessa maneira podemos entender que para que tenhamos consciência de nós mesmos, é preciso que nos voltemos para o outro, e esse movimento pode ser percebido como "alteridade". Com base nessa percepção do "Eu" e do "Outro, é crível pensar no movimento que existe entre a alteridade e a identidade, dentro da visão cultural de um povo, como o indígena e o caboclo. Em O rio comanda a vida (2000), Leandro Tocantis traz um panorama de como a natureza, sobretudo o rio, é parte essencial da vida do caboclo, o qual vive e usufrui daquilo que ela lhe fornece: a vida, em todos os aspectos. Para além do rio, elemento natural presente na vida desses nativos - indígena e caboclo/ribeirinho -, a natureza no geral, como veremos, faz parte da cultura e da formação identitária desse povo,

\footnotetext{
${ }^{4}$ CASTELLS, 1999, p. 23.

${ }^{5}$ PAGEAUX, 2004, p. 136.
} 
uma vez que por meio dela é que se tem o sustento da família e de toda uma comunidade, isto é, as raízes, a terra, a água, a fauna e a flora.

Contudo, é importante frisar que há uma diferença entre aqueles que vivem da/na natureza para os que vivem na capital, isto é, nos espaços rural e urbano, respectivamente (LOUREIRO, 1995, p.55). Este é composto pelo homem da cidade, habitante de Manaus e demais municípios, e aquele pelo homem rural, ou caboclo, também conhecido como ribeirinho, que vive na zona rural ou várzea do Amazonas. Essa divisão geográfica de culturas contribui para a totalidade da cultura amazônica juntamente com a indígena, resultando no homem amazônico, isto é, o conjunto desses povos que vivem na Amazônia, o qual entendemos como "homem amazônico".

Como se sabe, "a cultura está mergulhada num ambiente onde predomina a transmissão oralizada" (LOUREIRO, 1995, p.55), ou seja, o meio mais eficaz e utilizado por esse homem amazônico para transmitir e repassar a sua cultura será a fala, uma vez que ela é predominante entre eles e pela oralidade ter sido, de séculos passados até hoje, uma das ferramentas de preservação e permanência da cultura local, perpetuando-a.

A necessidade de transmissão dessa cultura é percebida, com maior veemência, no caboclo, ou ribeirinho, devido ao seu hábito de, diariamente, construir e ensinar, aos poucos, os seus costumes, e os de seus pais, para os seus filhos e netos, sendo ele o que mais representa a cultura amazônica, tanto pelo seu modo criativo, quanto ao seu acúmulo de experiências sociais. Isso se traduz como uma forma de preservação da cultura ribeirinha, pois "a cultura vem sendo considerada, desde a Antiguidade Clássica, como algo que engloba diferentes ângulos de uma totalidade voltada para a criação e preservação de bens materiais-imateriais, passando pelo cultivar, pelo habitar, pelo cuidar" (LOUREIRO, 1995, p.53).

É com o auxílio desses elementos que será possível a preservação da cultura, do bem material-imaterial, uma vez que ela é uma fonte bifurcada, dando origens aos costumes (materiais) e às crenças (imateriais), exercendo forte influência na vida dos ribeirinhos. Nos costumes estão inclusos os meios de sobrevivência e sustento básico do homem amazônico, como a caça e a pesca, a farinha de mandioca, a fabricação dos meios de transporte e utensílios (malhadeira, arrastão e arpão). Percebe-se que tudo é feito de forma artesanal, desde a produção do alimento até o modo de vida, à base natural, mas feitos grupalmente. 
Através disso, vê-se o contato extremamente próximo entre o homem típico da Amazônia e a natureza, especificamente um elemento encontrado nela: o rio.

O rio é o elemento natural com o qual homem amazônico mais tem contato e respeito. A relação entre eles é "impositiva", o rio dita as regras enquanto o homem aceita e a obedece (SANTIAGO, 1986, p. 84). Isso estabelece como o rio influencia na vida desse homem, uma vez que ele vive à mercê das circunstâncias naturais. É possível perceber a presença iminente da água, quando Bacellar (1985, p.12) diz no rondel da cajarana:

teu tronco em mágoa
no desengano
do mês pluvial
tem veios d'água
em seu tutano
manancial

A forte presença da água ressalva a vida, uma vez que a cajarana possui “veios d’água em seu tutano", remetendo-se à vitalidade que existe na fruta. E assim como a água e o rio são sinônimos de vigor, também podem ser a presença do envelhecimento e da morte, uma vez que "a imagem do rio pode ser estudada em três momentos muito importantes da vida social: o aniversário, o casamento e a morte" (SANTIAGO, 1986, p.77). O aniversário pode ser interpretado pela fase de envelhecimento do homem, a partida e chegada de um ano; o casamento pelo momento de importância instintiva do ser humano; e a morte como o momento de partida da vida, abandonando as construções feitas pela vida do homem até este ponto, tendo em todos esses momentos o aparecimento crucial do rio, dado que ele é o único meio para se chegar ao local de festejo e velório, por isso a sua obediência para com esse elemento natural.

Com isso, surgem as lendas e mitos folclóricos, que aparecem como uma reposta para a vontade da natureza; o respeito revela as faces pelas quais o homem amazônico é revestido sendo elas os seus costumes (caça e pesca), sensibilidade quanto ao seu ambiente e temor pela natureza, respondendo ao desconhecido de forma criativa. Assim, essas faces são variantes entre as sensações de felicidade, tristeza, alegria e medo, são, ainda, pela forma como ele traduz o meio onde vive, através do seu imaginário, formando sua identidade de homem da Amazônia. 
O imaginário desse homem amazônico é caracterizado pela maneira como pensa sobre o ambiente e acontecimentos que o rodeiam. Nesse contexto, Santiago (1986, p. 85) diz que "O processo de evolução do pensamento inicia-se no instante em que é percebida a necessidade de ordenar a realidade, de elaborar conceitos a respeito dos problemas humanos e por extensão orientar a reflexão sobre a natureza". Isto é, a necessidade do homem em manter o controle sobre aquilo que está além dele, está estritamente ligado com o que Loureiro (1995, p.61) diz em relação à sensação de pequenez, sendo ela o resultado do encontro do homem com aquilo que é imenso. Evidentemente, o ribeirinho é menor que o imenso, logo, causa nele um maravilhamento.

O imaginário do homem amazônico se dá pela relação do "perto-longe” (idem, 1995, p. 61), que tem vínculo com o seu lar, a natureza, mas longínqua por ser vasta e ele pequeno, se comparado a ela, e da "convivência-estranhamento", porque, apesar de anos vivendo naquele ambiente, ele não compreende determinados acontecimentos, como doenças desconhecidas.

Essas questões estão relacionadas à necessidade de resposta e solução quanto aos problemas que repercutem na sua vida e na sociedade em que estão inclusos, serão eles auxiliados tanto pela própria natureza, quanto pela religião, ou seja, o homem amazônico busca respostas e conceitos para aquilo que está além da sua capacidade humana a partir do sobrenatural, da sua religiosidade e cultura. Isso provém de uma mistura do reflexo da fé dos ribeirinhos e da herança da crença indígena, uma heterogeneidade que traz um caráter místico e panteísta, pois acreditam que, além da religião, a natureza é uma forte entidade, a qual rege sua vida e traça o seu destino (SANTIAGO, 1986). A partir disso, as lendas aparecem como forma de explicação para o desconhecido, como as doenças, assemelhandose aos povos indígenas que, também, viam as lendas como forma de explicação para todos os problemas aparentemente sem solução.

Um exemplo de como as lendas são agentes de explicações para o "novo", é a lenda do boto, o qual se transforma em um homem esbelto vestido de branco que encanta as moças ribeirinhas, levando-as para o fundo do rio e retornando-as para a superfície grávidas (explicação para quando a moça ficava grávida de pai desconhecido). As lendas não funcionam apenas para explicar fenômenos desconhecidos, mas como um presságio que visa livrar/alertar os ribeirinhos de males que possam vir a ocorrer, podendo ser exemplificado pelo hábito de pessoas mais velhas de determinado grupo reunir em roda as crianças do 
grupo e contar as lendas folclóricas, como da cobra grande, matinta pereira e do curupira, tendo sempre, ao final, uma lição ou ensinamento que será útil para a vida daqueles que as escutaram com atenção.

E não é apenas de religiosidade e de crença pela natureza que a identidade ribeirinha é formada. Ela provém de seus costumes, como a caça e a pesca, a própria produção do seu meio de transporte, que são a canoa e o barco, do alimento consumido, como a farinha de mandioca e o tucupi, dando a ele força para enfrentar a fúria da natureza, obstáculo da sua rotina diária.

Entretanto, nem sempre a prática da caça e da pesca é triunfal, ela poderá ser boa ou ruim, "os caminhos que andam trazem a fortuna ou a desgraça" (TOCANTINS, 2000, p.305), sendo esta atividade essencial muito perigosa, dado que, enquanto se pratica a ação de caça e pesca, o ribeirinho pode ser surpreendido pelas circunstâncias naturais e pela vontade dela, sendo isto representado pelos naufrágios, tendo a perda do alimento obtido com esforço, a própria morte, que causa temor neste homem amazônico, e as tempestades, sendo um fenômeno natural. O modo de vida, desde a pesca até a preparação artesanal dos seus utensílios de necessidade, demonstra a cultura peculiar do homem amazônico, sabendo lidar com o meio em que habita e equilibrando-o às suas necessidades. Em geral, a natureza não é um obstáculo para o caboclo da Amazônia.

Em situações de enfermidade, ele é quem produz seus remédios, a partir de plantas medicinais, as quais são encontradas na floresta amazônica e que, juntamente com sua fé, são capazes de curar até o incurável, prática herdada de seus ancestrais indígenas que preparam seus remédios a partir do que a natureza pode proporcionar. Isso estabelece a relação de obediência do ribeirinho quanto a ela e "são tamanhas as proporções do sentido das superstições na Amazônia que atingem todo o cosmos. O universo participa efetivamente da vida humana" (SANTIAGO, 1986, p.92).

Sendo assim, a vida do caboclo ou ribeirinho nunca é à deriva ou por coincidência, tudo tem seu significado através da natureza, da sua cultura, de seu imaginário e do universo, que, em conjunto, regem e direcionam a passagem desse homem amazônico na terra, enquanto viver, e protegem, assim, sua cultura, tirando-a do rumo do esquecimento, quase como um herói épico, o qual tem seus passos registrados de forma oral para que se perpetuem seus feitos e para que eles jamais caiam no esquecimento. 


\section{Umberto Eco e os bosques da ficção}

É sabido que a poesia é usada como meio de expressão ou imitação da realidade, como dizem Platão e Aristóteles, sendo uma válvula de escape do ser humano em relação às obrigações diárias exigidas pela sociedade e aprendizado sobre outras ciências. É um aprendizado, ainda, sobre a própria arte da criação como uma habilidade do homem, relacionado ao seu lado lúdico, ou seja, na mesma proporção que a mimeses está próxima à emoção e à poesia, a arte literária também distanciará do fazer racional que será a ciência filosófica, a ausência da incitação do humor, como defende Platão. Assim, a Poesia será classificada como ficção, por não se tratar de fatos, ou ainda, de estudo ao que é real, mas por praticar a representação ou imitação desse real, a partir das ações das pessoas, que no campo poético se tornarão as personagens ficcionais verossímeis à realidade, e da própria ação, a qual moldará as personagens que fazem parte da poesia e como peça-chave para a narrativa do texto. Esse caminho norteia para que pensemos como a Poesia é ficção e, como ambas, podem nos servir de fonte para compreender a cultura amazônica, isto é, culturas cabocla e indígena, que se fazem presente na obra de Bacellar, em outras palavras, temos dois grandes polos que se unem, de um lado a Poesia aliada à ficção que, por outro, nos permite ler e entender a cultura e o imaginário do caboclo e do indígena, todos presentes em Sol de Feira.

Retomando Platão, o filósofo infere sobre o que seria a poesia e a sua necessidade, o qual fala sobre Mimeses, nomeada dessa forma posteriormente por Aristóteles, e como ela é algo que degrada o homem e causa regressão intelectual a ele: “[...] quanto mais poéticas, menos convêm à audição de crianças e de homens que devem ser livres e temer a escravidão mais do que a morte" (RAMOS, 1965, p. 148).

O riso, o choro, a lamentação, ou seja, as emoções, estão relacionados às fraquezas e características indignas de homens honrosos e corajosos, elas são atribuídas àqueles que são tidos como vergonhosos para a sociedade, por se deixarem envolver pelas emoções que são, para Platão, a própria degradação humana e por isso deve ser reprimida enquanto há tempo, para que não "infecte" ou para que não "corrompa" aqueles que estão designados a proteger e, consequentemente, representar seu país. Sendo assim, a Poesia, segundo Platão, está relacionada à degradação do ser humano, pontuando que o texto narrativo é capaz de nos 
fazer visualizar aquilo que vemos diariamente e nos sensibilizar dessas mesmas cenas, que não nos causam comoção na realidade, mas no texto narrativo, ou seja, ficcional, sim.

Assim como Platão, Aristóteles também propôs o que seria arte literária, poesia e poeta, todavia, ao contrário de Platão, para Aristóteles a criação (poesia) é necessária para a vida humana, uma vez que ela serve como uma válvula de escape ao estresse e trabalho, dando vazão à imaginação e expressão ao que existe de mais profundo na alma humana: as emoções. E é ainda uma fonte de conhecimento, assim como as outras ciências daquela época, e isso significa que “[...] aprender é sumamente agradável não só aos filósofos, mas igualmente aos demais homens, com a diferença de que estes em parte pequenina. Se a vista das imagens proporciona prazer é porque acontece a quem as contempla aprender e identificar cada original;” (BRANDÃO, 2005, p. 22). Ou seja, o exercício da identificação ou de comparação de cada realidade é um ensinamento, tanto quanto o ato de filosofar e questionar. Desta forma, a arte de criar, a "literatura" /Poesia, tem a sua importância na vida humana e há um motivo para que ela exista: ela faz parte do desenvolvimento intelectual e lúdico do homem.

Apesar de Platão e Aristóteles convergirem quanto à utilidade e eficácia da arte de criar, da "literatura" e da poesia, ambos convergem com a ideia de que elas representam aquilo que vivemos através do imaginário, dando prioridade à emoção humana e daquilo que ele venha a desejar, divagar, e que de certa forma a poesia/ arte de criar é, sugestivamente, nato e faz parte do ser humano, sendo indissociável ao imaginário. Com base nisso, é possível inferir que a natureza da Poesia é ficção e está acima de categorias estruturais, uma vez que é a origem das outras estruturas e, para além disso, é expressão cultural do coletivo, assim como do individual.

Em sequência ao caráter ficcional encontrado na Poesia, ou ainda acerca da Ficção no campo literário, Walty (1999) considera a ficção mais do que o convencional significado dado a ela, de uma mera ilusão que deve ser refutada por não ser verdadeira, ou relacionada à ciência, mas que a ficção está presente no nosso dia a dia e através dela é verossímil traduzir a realidade, e isto equivale à nossa cultura e ao nosso imaginário.

Dessa forma, também, Umberto Eco falará sobre ficção em Seis Passeios pelos Bosques da Ficção, no entanto abrangerá muito além do que um conceito abstrato de o que seria ficção, mostrando as estruturas do texto narrativo ficcional, isto é, da narração. "Mas numa história sempre há um leitor, e esse leitor é um ingrediente fundamental não só do 
processo de contar uma história, como também da própria história" (ECO, 1994, p.7), assim como inferido tanto em Aristóteles e Platão, quanto em Walty, o leitor é o ingrediente principal de qualquer texto. Ele é a intercessão entre a obra e o autor, e é a partir dele que são perceptíveis os impactos que as obras causam na sociedade.

As diversas visões sobre um mesmo assunto ou tema só são possíveis pelos bosques que cada um encontra nos textos, como afirma Eco (1994, p. 12). Os bosques serão a peça essencial do texto ficcional, uma vez que, através dele, o leitor terá a oportunidade de deleitar-se e divagar pelos detalhes e maravilhamentos que o autor o possa proporcionar. Todavia, o objetivo dos bosques não serão, apenas, esse maravilhamento e deleite, mas, sobretudo, fazer com que seu leitor possa fazer reflexões sobre as temáticas e situações pontuadas no texto, analisando as personagens e as suas características, justificando alguns atos e dando possíveis porquês da reviravolta da narrativa, isto é, o leitor terá seus próprios pensamentos e julgamentos referentes ao texto lido. Esses pensamentos e julgamentos serão os bosques e as bifurcações, trilhas, que existem nele, são elas que possibilitam essa flexibilidade do texto de ter um caráter "bilateral" ou "multifacial", dá ao leitor esse leque de possibilidades e hipóteses para que ele pense e escolha o caminho mais sensato a seguir, lembrando sempre que não há retorno, somente ida, a não ser que ele volte ao início e trace uma nova trilha nesse bosque finito de sensações e capaz de fertilizar, da melhor forma, a imaginação do leitor.

Assim também será a narrativa ficcional, cheia de bifurcações, cabendo ao leitor escolher qual das direções seguirá, todavia, nem sempre as escolhas feitas resultaram no que é esperado pelo leitor porque isso depende dele e de seu autor, ambos são classificados por Eco como Leitor-empírico, Leitor-modelo, Autor-empírico e Autor-modelo. O Leitorempírico diverge do Leitor-modelo uma vez que ele é a pessoa concreta que se debruça sobre um livro para lê-lo. São, ainda, os leitores que “[...] podem ler de várias formas, e não existe lei que determine como devem ler, porque em geral utilizam o texto como receptáculo de suas próprias paixões, as quais podem ser exteriores ao texto ou provocadas pelo próprio texto" (ECO, 1994, p.14), ou seja, não cabe a ele anexar aos bosques particularidades de sua vida.

Em contrapartida, o Leitor-modelo é "“[...] um conjunto de instruções textuais, apresentadas pela manifestação linear do texto precisamente como um conjunto de frases ou de outros sinais" (ECO, 1994, p.22), aquele que é moldado pelo Autor-modelo durante uma 
narrativa e alvo do Autor-empírico durante a criação dessa mesma narrativa. O Leitormodelo, ainda, seguirá as regras ditas pelo autor, em qual direção ele deve seguir pelo bosque das narrativas ficcionais, deixando de lado suas experiências pessoais e seus sentimentos, dando lugar às características das personagens e do Autor-modelo encontrado no bosque. Por fim, o Autor-modelo é aquele que encontramos no texto, que nos narra a história, regindo e manipulando-a, para que o leitor faça o que ele quer ou acredite naquilo que ele deseja que acredite.

E a partir da trajetória pelos bosques da ficção, Eco constrói um conceito de Ficção mais abstrato, estando para a Literatura, divergindo de Walty com um conceito mais humanizado e para o real. A Ficção será crucial para a fertilidade da imaginação do leitor, servindo como fonte de pesquisa e fonte enriquecedora da Literatura, tendo um caráter multifacetado, utilizado de várias formas pelos autores. A Ficção, assim como a Literatura, para Eco, estaria voltada mais para a estrutura do que para a função social.

Por outro lado, Candido dará um conceito mais humano ao fazer literário, assim como Walty, abordando sobre as funções da literatura. Para que seja abordada as funções da literatura, ou seja, a função social, humanizadora, é necessário voltar-se às questões estruturais, uma vez que a estrutura também é um objeto de estudo da literatura e da forma.

O ponto de vista estrutural consiste em ver as obras com referências aos modelos ocultos, ponto pelo menos provisória e metodicamente entre parênteses os elementos que indicam sua gênese e a sua função num momento dado, e que portanto acentuam o seu caráter de produto contingente mergulhado na história (CANDIDO, 1972, p.82).

Assim, a visão estrutural visa a parte teórica da obra, ou seja, os elementos sintáticos, estruturais e a gênese da obra, e não o impacto que ela causa no leitor, a sua função social. Além disso, a Literatura funciona como uma lupa na busca daquilo que é microscópico ou sutil: a identidade. É através da literatura que o homem busca encontrar-se, se conhecer e conhecer aquilo que ele acredita. A identificação com as obras literárias é fundamental para que aconteça a sua função humanizadora.

Por isso, o homem necessita da obra e do fazer literário, ou seja, tanto da leitura quanto da escrita. Candido (1972, p. 83) infere sobre isso ao falar da necessidade do homem à ficção e à fantasia: "A produção e fruição desta se baseiam numa espécie de necessidade universal de ficção e de fantasia, que decerto é coextensiva ao homem, pois aparece 
invariavelmente em sua vida, como indivíduo e como grupo, ao lado da satisfação das necessidades mais elementares".

Essa necessidade universal da ficção e da fantasia se dá pela identificação com as obras e as estórias contidas nelas, pelo narrador e sua personalidade, bem como as personagens. A questão da ficção e da fantasia está voltada para aquilo que conhecemos como obras literárias, e assim como essas obras são libertadoras ao homem, por sua capacidade de humanização e reflexão, ela também pode ser alienadora, por poder causar a ruptura e distanciamento entre as realidades sociais humanas, dependendo de como isto é inferido na obra, isso será o paradoxo da literatura.

As obras literárias são, apesar de não estarem vinculadas à realidade, um reflexo do real, uma vez que sua criação é inspirada nele e, portanto, capaz de realizar a função social da literatura, pela projeção de uma imagem e/ou situação do nosso dia a dia que, no mundo real, não é capaz de nos sensibilizar pela banalização de situações desumanas, mas que o poeta, por meio das palavras, consegue (re)humanizar e sensibilizar seu leitor para o que ele vê, mas passa despercebido pelo frenesi da vida.

A retomada da humanidade do leitor pelo poeta se criará através da fantasia e da ficção, e elas se mostram necessárias para a vida humana, porque são a partir delas que o homem encontra a sensibilidade do mundo, as respostas para aquilo que não consegue responder (cientificamente), como os mitos e lendas - elementos constituintes da identidade cultural e do imaginário do homem amazônico, advindos da natureza -, um reflexo sólido da presença e necessidade desses dois elementos à vida humana, presentes em obras literárias e artísticas, forma de expressão do que se entende sobre o mundo e, também, uma resposta sobre ele.

\footnotetext{
Portanto, por via oral ou visual; sob formas curtas e elementares, ou sob complexas formas extensas, a necessidade de ficção se manifesta a cada instante; aliás, ninguém pode passar um dia sem consumi-la, ainda que sob a forma de palpite na loteria, devaneio, [...]. E assim se justifica o interesse pela função dessas formas de sistematizar a fantasia, de que a literatura é uma das modalidades mais ricas (CANDIDO, 1972, p.83).
}

Com isso, pode-se pensar na função do devaneio, que ele é essencial para que haja ficção e fantasia, para que o homem possa encontrar um caminho para identificar-se naquilo que já foi banalizado no real, por isso "O devaneio seria o caminho da verdadeira 
imaginação, que não se alimenta dos resíduos da percepção e, portanto, não é uma espécie de resto da realidade; mas estabelece séries autônomas coerentes, a partir dos estímulos da realidade" (idem, 1972, p.83). E seu ponto de partida será a realidade sensível do mundo, pois é a partir dela que a função social da literatura se dará, de forma que traga a sensibilidade de volta aos olhos dos homens que tiveram sua realidade sensível banalizada pela metódica rotina do mundo capitalista no qual estão inseridos, assim cegando-os para o que está diante dos seus olhos e que a literatura é capaz de trazer novamente: a humanização do homem.

Da mesma forma, a poesia adentrará nesse homem, mas que nesta face é leitor. A poesia adentrará através do poema que é “[...] independente do seu criador, tem vida própria, mas somente comunica poesia em nós: sem o leitor, é letra morta ou hieróglifo à espera da decifração" (MOISÉS, 1997, p.91). Se faz então necessária a presença e falar-se do leitor quando se trata de poesia porque "o leitor reproduz o estado lírico do poeta, enriquecido das sugestões do poema, emanadas da fixação daquilo que ao próprio criador do poema era absolutamente insuspeitado" (idem, 1928, p.90), ou seja, somente o leitor é capaz de desvendar e emanar aquilo que nem mesmo o poeta consegue expressar, nem mesmo aquilo que ele suspeitou que fosse possível passar nos seus poemas: a poesia.

Por sua vez, a poesia

[...] é conhecimento, salvação, poder, abandono. Operação capaz de mudar o mundo, a atividade poética é revolucionária por natureza: exercício espiritual, é um método de libertação interior. A poesia revela este mundo, cria outro. Pão dos escolhidos; alimento maldito. Isola; une. Convite à viagem: retorno à terra natal. Inspiração, respiração, exercício muscular. Prece ao vazio, diálogo com a ausência: o tédio, a angústia e o desespero a alimentam. [...] Experiência inata. Visão, música, símbolo. Analogia: o poema é um caracol onde ressoa a música do mundo e metros e rimas são apenas correspondências, ecos, da harmonia universal. Ensinamento, moral, exemplo, revelação, dança, diálogo, monólogo. Voz do povo, língua dos escolhidos, palavra do solitário. Pura e impura, sagrada e maldita, popular e minoritária, coletiva e pessoal, nua e vestida, falada, pintada, escrita, ostenta todos os rostos mas há quem afirme que não possui nenhum: o poema é uma máscara que oculta o vazio, bela prova da supérflua grandeza de toda obra humana! (PAZ, 2012, p.21).

A poesia é, então, universal. Por isso ela possui esse caráter, até pensável como "contraditório", porque é cabível a tudo e a todos, e ao mesmo tempo a nada. Da mesma 
forma que ela pode afagar aquele que sofre, ela também pode castigá-lo, num só verso, numa só sensação, bem como já dizia Eco sobre os bosques ficcionais e como Candido fala sobre a Literatura: da mesma forma que o leitor se identifica, pelo bem, ele se identifica pelo mal. Esse processo "multifacetado" da poesia através do poema gera aquilo que, podendo-se afirmar, a poesia procura, bem como a literatura: tocar o ser humano e fazê-lo mais humano pois somente uma obra humana poderá tocar outra obra humana, o ser humano advindo de outro ser humano.

E esse ciclo só ocorre porque "o poema é uma obra sempre disposta a ser completada e vivida por um novo leitor" (PAZ, 2012, p.198), apesar de poesia e o poema serem termos independentes (MOISÉS, 1997), mas são indissociáveis ao leitor, para que ocorra o efeito poético, o fazer literário da criação das imagens, pois "a leitura do poema tem grande semelhança com a criação poética. O poeta cria imagens, poemas; e o poema faz do leitor imagem, poesia" (PAZ, 2012, p.33).

É necessário o leitor e é no leitor que o poema reafirma a sua universalidade porque

O poema é uma possibilidade aberta a todos os homens, qualquer que seja seu temperamento, seu ânimo ou sua disposição. Pois bem, o poema é apenas isto: possibilidade, algo que só se anima em contato com um leitor ou um ouvinte. Há um traço comum a todos os poemas, sem o qual eles nunca seriam poesia: a participação (idem, 2012, p.33).

E como observado, a poesia, através do poema, desperta aquilo que de mais humano possa existir no ser humano: a emoção e o pensamento. É conhecer a emoção e o pensamento no que diz respeito à experiência universal e saber observar os seus significados quanto ao fenômeno poético, a própria poesia. É perceber que além do leitor existe um poeta, e ele tornará capaz a construção das imagens em um poema, como diz Paz (2012, p.31)

O artista é criador de imagens: poeta. E sua qualidade de imagens permite chamar de poemas o Cântico espiritual e os hinos védicos, o haicai e os sonetos de Quevedo. O fato de serem imagens faz as palavras, sem deixar de ser elas mesmas, transcenderem a linguagem enquanto sistema dado de significações históricas. O poema, sem deixar de ser palavra e história, transcende a história. Examinando com atenção em que consiste esse transpassar a história, é possível concluir que a pluralidade de poemas não nega, e sim afirma, a unidade da poesia. 
Portanto, o poema através da materialização de imagens, é capaz de transcender a história, é atemporal; torna não somente o poema como universal e atemporal, mas a poesia também, uma vez que ela é capaz de ser sentida e estudada não só no momento presente, mas no passado e no futuro, isso lhe dá o caráter transcendental. Ela é capaz de unir gerações e gerações com apenas a ferramenta chamada "palavra" que consegue ultrapassar o verbal e torna-se imagético.

Ela será peça chave para expressão do poeta, que através da poesia transborda o seu eu e aquilo que não cabe dentro de si, as suas experiências, as suas emoções, sua humanidade. Ele estabelecerá uma relação entre seu ego versus o "eu do poema", transformando isso de tal forma que não exista nem um nem outro, mas uma "entidade coletiva”, que refletirá naqueles que leiam e não no individual, inferido por Moisés (1997, p.141). E além dele, há as vozes dos poemas, que se distinguem pelo real e fictícia, estando aquela para o que se expressa no poema, como inferido anteriormente, e esta para o próprio autor em si, porque a sua produção equivale e está para a sua imaginação, e esta por sua vez não diz respeito a fatos ou a realidade, ela diz respeito tão e somente aquilo que é criado e desejado pelo ser humano: sua imaginação (MOISÉS, 1997, p.140)

Portanto, poema está para a poesia, bem como o homem está para a imaginação, e apesar de serem independentes eles são indissociáveis, uma vez que em um é possível encontrar o outro, assim como nos poemas, através da poesia, é possível se identificar com um personagem e injetar naquela obra as suas emoções e sua vida, a procura incansável em identificar-se no outro, como inferido por Eco (1994), seja esse outro um personagem, uma pessoa ou uma obra, faz parte da condição de ser humano afastar-se da condição de leitormodelo e aderir àquilo que são, inicialmente, leitores-empíricos, sem quaisquer regras ou sem ordens, apenas fazendo aquilo que bem quer e transbordando na Arte o que de mais puro, e mais humano, existe em si: as emoções, as experiências, as histórias, todas fruto do imaginário e cultura humana, respectivamente. O breve panorama sobre poema, poesia, literatura e ficção é para que, por fim, possamos compreender como esses elementos da Arte são parte de um todo, um quebra-cabeça que nos leva, e nos retorna, aos conceitos desenvolvidos sobre cultura, imaginário, identidade e alteridade, uma vez que tudo isso é encontrado em uma obra literária que, por sua vez, é poesia, é fictícia, é literatura. 


\section{Sol de Feira: cultura e imaginário no pomar da ficção}

Para que haja poema, e nele Poesia, é preciso o poeta. O poeta é quem dará vida e voz aos sentimentos humanos mais remotos, que, por muitas vezes, tornar-se-á universal pela identificação do público-alvo, ou quaisquer que sejam "o coração partido" ou, ainda, a imaginação. Assim, o poeta será o intercessor entre poema e leitor, mediando um mundo vasto e peculiar existente em si e que é capaz de despertar e libertar o mundo existente noutro e, desta maneira, teremos Luiz Bacellar como intercessor da poesia erudita no Amazonas.

De forma breve,

Luiz Franco de Sá Bacellar nasceu em Manaus, no dia 4 de setembro de 1928. [...]. Foi professor de Literatura e Língua Portuguesa no Colégio Estadual Pedro II e um dos fundadores do Clube da Madrugada. Em 1959 ganhou o prêmio Olavo Bilac, da Prefeitura Municipal do Rio de Janeiro, com o livro Frauta de barro, obra que, publicada apenas em 1963, marcou sua estreia literária. Outras obras poéticas: Sol de feira (Manaus, 1973), Quatro movimentos (Manaus, 1975), O Crisântemo de cem pétalas, em parceria com Roberto Evangelista (Manaus, 1985), Quarteto (Manaus, 1998) e Satori (Manaus, 2000) (TELLES; KRÜGER, 2006, p.143).

Portanto, é possível observar a importância de Luiz Bacellar para a literatura no Amazonas, como um dos pioneiros do movimento Modernista no Amazonas com a criação do Clube da Madrugada e com obras que abordam temáticas regionais e que preservam a memória e cultura amazonense.

Em suas obras, Bacellar busca dar ênfase à vida do homem amazônico (caboclo) e à sua cultura, preservando, desta forma, as suas origens e as riquezas do Amazonas, nelas estão a fauna e a flora, os costumes; faz presente a memória de quem viveu a Manaus entre os anos 60 e 70, caracterizando-se saudosista em suas obras e, sobretudo, com poemas de alto lirismo que, singelamente, perpassam o que de mais sutil e significativo há na cultura amazonense, a sua essência: o homem amazônico.

Por meio do homem amazônico e de muitos outros elementos que constituem a cultura amazônica como os hábitos, comidas típicas, imaginário etc., Bacellar criará uma de suas obras-primas, Sol de Feira. Nela, o autor-modelo conduzirá o leitor-modelo a um passeio por uma feira regional, na qual são expostas através de rondeis as frutas típicas da Amazônia, mostrando a esse leitor um pouco do que é composto a Amazônia, como o 
imaginário amazônico, a cultura, as frutas (elemento principal do livro, as quais comporão o homem amazônico como um todo).

E em meio a esse pomar da ficção, uma vez que mostra aquilo que advém do imaginário amazônico criando sua cultura, o leitor-modelo, aquele que entrará no mundo dos caboclos através de Sol de Feira, criará imagens mentais que o farão materializar as frutas, com uma imagem única e peculiar delas, como é percebido nos rondeis a serem analisados: rondel da castanha, rondel do tucumã e rondel do abiu.

Na página 29 o leitor deparar-se-á com o rondel da castanha:

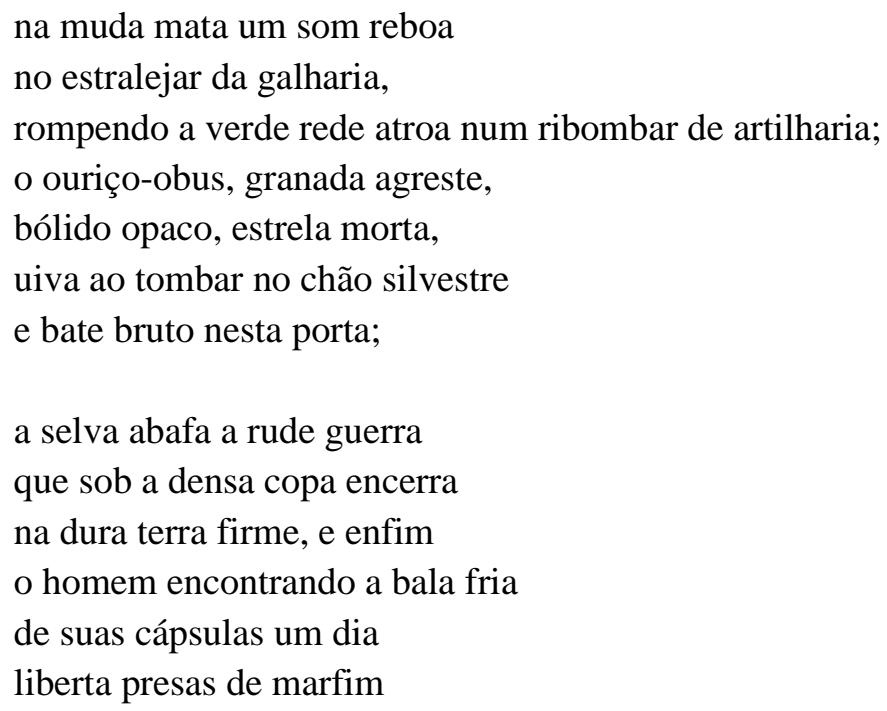

O autor informa ao leitor que a castanha é um fruto que se dá na mata, acolhido dentro de um ouriço o qual o "som reboa no estalejar da galharia, rompendo a verde rede atroa num ribombar de artilharia;", ou seja, o som emitido do choque do ouriço com o solo causa um barulho surdo, como o de armas de fogo; e continua: “o ouriço-obus, granada agreste, bólido opaco, estrela morta [...]", nestes versos o autor continua a sua ênfase ao fruto, para que assim se concretize a materialização da imagem na mente do leitor, sendo guiado por aquilo que o autor lhe infere, dizendo-lhe que a castanha é bola de fogo (pela força com a qual tomba "no chão silvestre"), é "granada agreste", intensificando a materialização do ouriço da castanha: robusto, resistente e duro. E ao equipara-la a "estrela morta", faz-se necessário o significado simbólico de tais palavras.

À estrela “[...] costuma-se reter sobretudo sua qualidade de luminar, de fonte de luz. [...]. As estrelas transpassam a obscuridade;" (CHEVALIER; GHEERBRANT, 1991, p.404) 
e à morte "perecível e destrutível da existência. [...] é revelação e introdução. Todas as iniciações atravessam uma fase de morte, antes de abrir o acesso a uma vida nova" (idem, 1991, p. 621).

Isto é, a castanha encontra-se transpassando a escuridão (na copa das castanheiras), no entanto a sua madurez faz-se necessária e a castanha rompe os céus, dando fim a um ciclo para que seja iniciado outro: a alimentação do caboclo. Este ciclo é enfatizado nos seguintes versos, nos quais Bacellar descreve o processo de maturação da fruta, a queda do ouriço e colheita pelo caboclo; observa-se, ainda, que o autor diz que as castanhas são "presas de marfim”, e o marfim tem por sua vez a simbologia ao resistente, poderoso e persistente à corrupção (CHEVALIER; GHEERBRANT, 1991, p.593 a 594), sendo assim a castanha símbolo de pureza, luz mas ao mesmo tempo remete-nos ao fim de um ciclo, o qual remetenos à própria vida humana, nascimento, crescimento e morte, pelo ciclo o qual a castanha passa até ser consumida; isto dá uma ideia do deste por aquele, algo que pode-se observar como dizer a fruta para entender o ser humano (caboclo), através do poema.

Essa ideia de "dizer o outro" chama-se alegoria. Moisés (2013, p.14) define alegoria como "[...] discurso acerca de uma coisa para fazer compreender outra [...]"; Bacellar, através do poema, discorrerá sobre as frutas, mas dizendo o caboclo, perceptível numa análise além do texto porque a alegoria extrapola as palavras, encontra-se no âmago do discurso, nas entrelinhas. E, além disso, a carga cultural exposta em Sol de feira torna-a uma obra propriamente alegórica, como diz Kothe (1986, p.53) sobre a cultura ser alegoria.

À medida que a alegoria "diz o outro", essa busca da alteridade semântica (impulsionada pela realidade) acaba se contrapondo à sua convencionalidade. E sendo "ex-pressão" do econômico" aquilo que se costuma chamar de "cultura" [...] a cultura é então algo essencialmente "alegórico". Para compreendê-la é preciso, portanto, entender a alteridade, o outro de que ela é expressão.

Sendo assim, para que seja fazível a compreensão do caboclo em Sol de feira, é necessária a análise das frutas porque nelas encontra-se o caboclo, e somente nela é possível a percepção da cultura amazonense e de sua importância nela. No entanto isto "não se trata só de ver o outro, mas de um dizer que presentifica o outro, em que o outro se torna presença. A leitura alegórica pretende compreender esse jogo em que um não elimina o outro, mas 
inclusive o relembra constantemente" (KOTHE, 1986, p.75). Dessa forma, o caboclo, seu imaginário e sua cultura são refletidos no rondel do abiu (p.41):

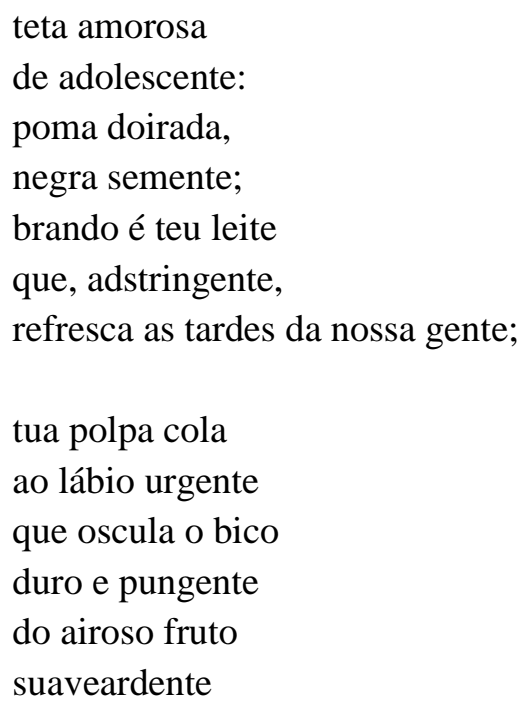

Ao dizer "teta amorosa de adolescente: poma doirada, negra semente;" Bacellar diz do seio da adolescente (cabocla) através do abiu, aproximando, senão dizendo, o abiu como parte do corpo do homem amazônico, evidenciando a sua importância a ele, e como ambos estão ligados através de uma entidade que encontra-se subentendida: a natureza; a fruta como integrante essencial da cultura do homem amazônico é entendida pelo seu contato direto com a natureza, trazendo-a para a sua vida e deixando-a fazer parte dela.

Assim, o abiu é fruta presente no lanche dos homens amazônicos: "brando é teu leite que, adstringente, refresca as tardes da nossa gente", reafirmando a presença da natureza e da sua necessidade para aqueles; e o selo com a natureza, através do abiu, é selado através do beijo no décimo verso, quando o autor diz que os lábios osculam o fruto. O beijo é "símbolo de união e de adesão mútuas que assume, desde a Antiguidade, uma significação espiritual.[...], o beijo é o signo da unidade" (CHEVALIER; GHEERBRANT, 1991, p.127 a 128), ou seja, esse gesto sela e reafirma a união entre natureza e caboclo.

Ademais, não só se observa a ligação da natureza com cultura do homem amazônico, mas o seu imaginário ligado ao de outras sociedades como será explicitado no rondel do tисита̃ (p.41): 


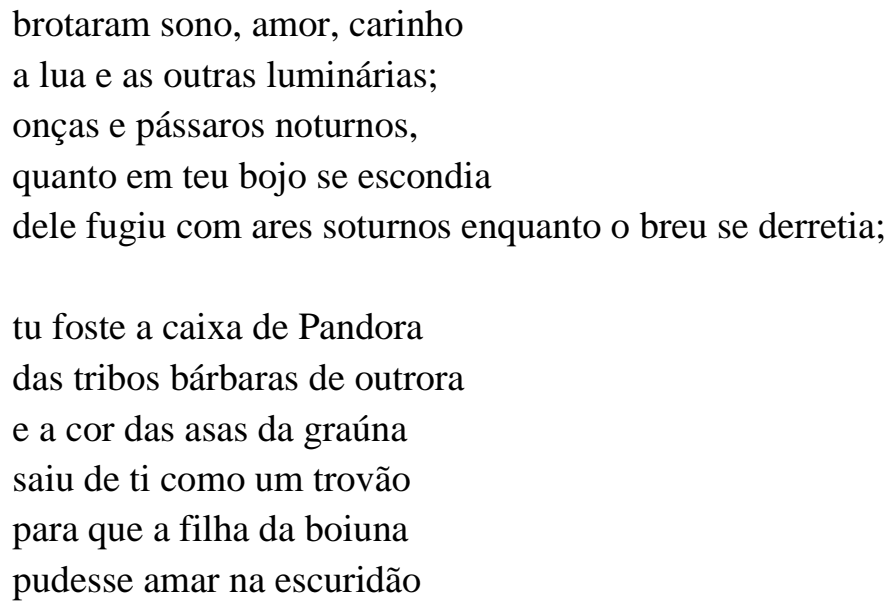

Na primeira estrofe, Bacellar discorre sobre o nascimento da luz e da treva, bem como os males e as bondades que a eles estão associados e que deles brotaram, a partir do caroço do tucumã. Isto está relacionado ao imaginário caboclo no que diz respeito às lendas; a explicação da criação do "bem e mal" e "luz e treva" advinda do tucumã é uma lenda indígena (que perpassam para o caboclo e suas gerações), mas que faz parte do imaginário caboclo também. No entanto, há um diálogo único feito por Bacellar que consiste na aproximação da mitologia grega à mitologia indígena: a comparação do tucumã com a caixa de Pandora. Pandora é

A criatura esculpida por Hefesto [...] que significa dotada por todos. Dona de um caráter intratável e agraciada com a arte de seduzir e um exímio espírito de dissimular, ela traz consigo uma caixa [...] que contém todos os males do mundo e que vai parar nas mãos de Epimeteu: todas as desgraças escapolem e se abatem sobre a humanidade, salvo a esperança [...] que ficaria imobilizada sob a tampa (BRUNEL, 1998, p.785),

ou seja, a mesma função que a caixa de Pandora exerce na mitologia grega o tucumã exerce na mitologia indígena, um arquétipo; explicando a coloração do pássaro-preto (graúna) mas, sobretudo, o motivo pelo qual a escuridão escapou do tucumã: "para que a filha da boiuna pudesse amar na escuridão". Boiuna é um dos nomes que designam a cobra-grande, que vive nas profundezas dos rios e lagos e a qual faz parte de uma das lendas amazônicas; fala sobre o nascimento de dois fetos concebidos pela cobra-grande com uma humana, denominados Honorato e Maria. Ambos enfatizam a relação de bem e mal, uma vez que Maria era perversa e Honorato era o seu inverso, estabelecendo uma relação de opostos (apesar da mesma vivência e da mesma forma de criação). 
O imaginário e a cultura do homem amazônico são entrelaçados à natureza em Sol de feira como reafirmação e selo dessa relação que extrapola o real e transcende através dos poemas como os de Luiz Bacellar e em obras como esta; sobretudo, a ficção está inserida nela justamente porque extrapola o real e não pelo estereótipo o qual a palavra está vinculada (da mentira), dando vez ao imaginário que envolve mistérios e subjetividade coletiva, sendo uma construção admirável já que advém de histórias construídas por esse povo e pela sua fé. O livro faz-se através das imagens que o autor modelo cria, uma vez que ele é quem traça os caminhos a serem percorridos na obra, através de descrições, alegoria e comparações, fazendo com o que o seu leitor modelo não só conheça as frutas, mas compreenda a carga cultural que elas carregam, a sua importância, logo, extrapola a um simples passeio a uma feira, mas sim o passeio pela cultura e imaginário amazônico pelo pomar da ficção da obra Sol de feira.

\section{Considerações finais}

Luiz Bacellar foi, e é, um autor inventivo, o qual criou diversas obras magnificas em diversos aspectos e que até hoje são estudadas no ensino superior e médio. Através delas é possível conhecer e aprender um pouco sobre a vida amazonense, sobretudo ribeirinha, a partir da lente de um nativo da Amazônia. Com isso, Sol de Feira (1967) encaixa-se como uma das obras-primas de Bacellar, a qual, de forma lírica e harmoniosa, une homem e flora (da Amazônia), trazendo ao leitor não só a cultura e imaginário amazônico, mas também informações biológicas (fauna e flora) sobre a Amazônia. O pomar elaborado por Bacellar, nos revela a forte ligação do caboclo e do indígena à natureza, todos que, em um conjunto, se mesclam com poesia, literatura e ficção.

E por meio de Eco, vê-se como a alegoria relaciona o livro de Bacellar à ficção, pela reflexão do real, mas ao mesmo tempo estando no campo o qual extrapola a realidade: o imaginário.

Desta maneira, obtém-se o resultado: a cultura e o imaginário do homem amazônico no pomar da ficção; depreendendo-se a relação do imaginário ao ficcional, mas não relacionado ao inexistente, falso ou, ainda, falacioso; na verdade extrapola o real pela sua forma de poder estar relacionada à imaginação humana que esta, por sua vez, não é falsa porque baseia-se 
de acordo ao que é existente ou foi vivido pelo ser, bem como também se une àquilo que está além do real ou palpável, divino.

\section{Referências}

BACELLAR, Luiz. Sol de feira. 3. ed. Manaus: Puxirum, 1985.

BOAS, Franz. Antropologia Cultural. Tradução de Celso Castro. Rio de Janeiro: Zahar, 2004.

BRUNEL, Pierre (org.). Dicionário de mitos literários. Rio de Janeiro: José Olympio, 1998.

BRANDÃO, Roberto de Oliveira (org.). Aristóteles, Horácio, Longino: A poética clássica. 12 ed. São Paulo: Cultrix, 2005.

CANDIDO, Antônio. “A literatura e a formação do homem”. In: Ciência e Cultura. Vol.24 $n^{\circ}$ 9. Set. 1972.

CASTELLS, Manuel. O poder da identidade: volume II. $3^{\text {a }}$ edição. Tradução de Klauss Brandini Gerhardt. São Paulo: Paz e Terra, 1999.

CEIA, Carlos. S.V. “Alteridade”. IN: E-Dicionário de Termos Literários (EDTL), coord. de Carlos Ceia, ISBN:989-20-0088-9. Disponível em: ALTERIDADE - E-Dicionário de Termos Literários (unl.pt). Consultado em: 12/01/2022.

CHEVALIER, Jean; GHEERBRANT, Alain. Dicionário de símbolos. 5. ed. Rio de Janeiro: José Olympio, 1991.

ECO, Umberto. Seis passeios pelos bosques da ficção. São Paulo: Companhia das Letras, 1994.

KOTHE, Flávio R. A Alegoria. São Paulo: Ática, 1986.

LARAIA, Roque Barros. Cultura: um conceito antropológico. $27^{\mathrm{a}}$ reimpressão. Rio de Janeiro: Zahar, 1986.

LIMA, Deborah de Magalhães. A construção histórica do termo caboclo: sobre estruturas e representações sociais no meio rural amazônico. Novos Cadernos NAEA, vol. 2, n. 2, p. 5 32, dez. 1999.

LOUREIRO, João de Jesus Paes. Cultura amazônica: uma poética do imaginário. Belém: Cejup, 1995.

MOISÉS, Massaud. A criação literária - poesia. 13 ed. São Paulo: Cultrix, 1997. 
, Massaud. Dicionário de termo literários. 12 ed. São Paulo: Cultrix, 2013.

PAGEAUX, Daniel-Henri. "Da imagética cultural ao imaginário”. IN: BRUNEL, Pierre; CHEVREL, Yves (orgs.). Compêndio de literatura comparada. Lisboa: Fundação Calouste Gulbenkian, 2004.

PAZ, Octavio. O arco e a lira. São Paulo: Cosac Naify, 2012.

RAMOS, Vítor (org.). PLATÃo, A REPÚBLICA. São Paulo: DIFUSÃO EUROPEIA DO LIVRO, 1965.

SANTIAGO, Socorro. Uma poética das águas. Manaus: Puxirum, 1986.

SANTOS, José Luiz dos. O que é cultura. 6 ed. São Paulo: Brasiliense, 1994.

SARTRE, Jean-Paul. O ser e o nada - Ensaio de ontologia fenomenológica. Tradução de Paulo Perdigão. 20a ed. Petrópolis, RJ: Vozes, 2011.

TOCANTINS, Leandro. O rio comanda a vida - uma interpretação da Amazônia. 9. ed. Manaus: Valer/Edições Governo do Estado do Amazonas, 2000.

TELLES, Tenório e KRÜGER, Marcos Frederico. Poesia e poetas do Amazonas. Manaus: Valer, 2006.

WALTY, Ivete Lara Camargos. O que é ficção. São Paulo: Brasiliense, 1999.

Artigo recebido em: 14.08.2021

Artigo aceito para publicar em: 09.01.2022 